\title{
Assessment of Fat Grafting in Enhancing the Middle Eastern Buttocks
}

\author{
MOHAMED YOUSSEF, M.Sc.; HEBA HUSSEIN, M.D.; AMIR EL-BARBARY, M.D. and \\ MOHAMED ABDEL MOHSEN GHANEM, M.D. \\ The Department of Plastic and Reconstructive Surgery, Faculty of Medicine, Ain Shams University, Cairo, Egypt
}

\begin{abstract}
Background: Fat survival remains a challenge following fat grafting and has been a subject of debate. The key to successful fat grafting in buttock enhancement dictates familiarity with the technique, knowledge of the gluteal topography and aesthetics along with understanding of the patient's desired needs and goals. However, several areas still need to be researched.
\end{abstract}

Objectives: This study aims to describe the anthropometric measurements of the Middle Eastern female buttocks and to evaluate the post-operative volume changes of structural fat grafting following gluteal enhancement procedures.

Methods: This study included sixty adult healthy females. Candidates were classified into four main groups; control group (30 candidates) for measuring anthropometrics of Middle Eastern buttocks with normal BMI, and other 30 candidates were grouped into three surgical groups (10 candidates for each) according to the amount of fat grafting. Anthropometric measurements were obtained directly through patients' photos (posterior and lateral views) pre-operatively, 3 and 6 months postoperatively. Pre-operative volume of gluteal region in each quadrant was measured for the whole buttock by using the ultrasound then compared to that of 3 and 6 months post-operatively.

Results: Control group (30 candidates) showed that round shape buttocks was the dominant shape. Fat survival rate of fat injected in subcutaneous plane decreased with increasing volume of fat injected, while in the intramuscular plane the survival rate the same and was not affected significantly.

Conclusion and Recommendations: Round shaped buttock is the dominant shape in Middle Eastern buttock; fat survival rate is greater when injected intramuscular. We warn surgeons from trying intramuscular fat injection without anticipating problems and also without taking in consideration precautions and recommendations especially in large volume grafting.

Also, we recommend authors to perform more studies in Middle Eastern buttocks for more control cases to confirm the anthropometric criteria of Middle Eastern buttocks.

Key Words: Fat-Grafting - Buttocks.

\section{INTRODUCTION}

Gluteal lipoinjection in conjunction with liposuction has become one of the most frequently performed procedures in cosmetic surgery to achieve improvement of the body contour [1].

Shape of the buttock is determined mainly by four anatomical variables; bony framework, gluteus maximus muscle, subcutaneous fat topography, and Skin. The particular shape of buttock is determined by the interaction between these four variables. Four basic frame types of buttocks have been described by Mendieta in 2003: Square, round, A (pear) and V (apple) shapes [2].

Different modalities have been used to augment buttocks including gluteal implants [3], autologous fat grafting [4] or synthetic fillers [5]. Fat grafting has been used commonly for body contouring and is considered to be a reliable method for buttock remodeling [6]. Fat grafting has fewer complications if compared to the use of implants such as extrusion, capsular contracture, rupture and flat contouring of the inferior part of the buttock [7]. Fat, as autologous tissue, is considered the ideal soft tissue filler as it is abundant, inexpensive, host compatible, readily available and can be harvested easily and repeatedly. Moreover if fat grafting can truly survive following transplantation, it may presents a safe, long-lasting, natural appearing technique for soft tissue augmentation in patients.

Although the ideal plane of fat grafting either subcutaneously or intramuscular is still debatable, Subcutaneous-only gluteal fat grafting is now increasingly recommended over intramuscular grafting to improve safety. Despite the perception that subcutaneous grafting results in less volume retention [8].

Fat survival remains a challenge after fat grafting and has been a subject of debate. The key to successful fat grafting in buttock enhancement dictates familiarity with the technique, knowledge of the gluteal topography and aesthetics along with understanding of the patient's desired needs and 
goals. With experience the surgeon can predict the amount of volume needed for grafting to produce the desired results. However, several areas still need to be researched. The amount of take \& longevity of the grafted fat along with the standards of the Middle Eastern female buttock aesthetics to be reproduced remain among these areas.

\section{Aim of this study:}

This study aims to describe the anthropometric measurements of the middle eastern female buttocks and to evaluate the postoperative volume changes of structural fat grafting following gluteal enhancement procedures.

\section{PATIENTS AND METHODS}

This study was conducted at Ain-Shams University Hospitals and included sixty adult healthy females. Candidates were classified into four main groups; Control group for anthropometric measurements including 30 candidates, age ranging 1825 years with normal range of body mass index (18 to 25), normal buttock measurements, all patients are satisfied by their appearance and their aesthetic pleasing buttock. Anthropometric measurements were conducted directly on this group including; (1) Sacral height in relation to intergluteal crease, (2) The inter gluteal crease in relation to the length of the central vertical mid buttock line, (3) The angle between inter-gluteal crease and upper inner thigh, (4) The lower lateral gluteal with leg junction angle, (5) Mid lateral gluteal with hip junction angle to determine if these angles are smooth, moderate or sharp demarcation as shown in Fig. (1).

\section{Surgical groups:}

These surgical groups were including 30 candidates with age ranging 18-40 years. All fat cells were injected directly without centrifugation into two planes; the subcutaneous and the intramuscular one.

- Group 1: Including ten candidates with less than $400 \mathrm{cc}$ of grafted fat cells were injected into the gluteal region.

- Group 2: Including ten candidates from 400 to $800 \mathrm{cc}$ grafted fat cells were injected into the gluteal region.

- Group 3: Including ten candidates with more than $800 \mathrm{cc}$ of grafted fat cells were injected into the gluteal region.

Candidates were preoperatively assessed by; Full history, general and local examination along with recording the height, waist circumference, breast circumference, and thigh length.
Anthropometric measurements were obtained directly through patients' photos (posterior and lateral views).

\section{Posterior view:}

The following points were marked; posterior iliac spine, anterior iliac spine, iliac crest, points of sacral triangle, point A (most protruding point in the upper lateral hip), point B (most protruding point in the lateral thigh) and point $\mathrm{C}$ (lateral mid buttock) to determine the buttock frame type.

The following measurements were recorded; (1) The sacral height in relation to inter gluteal crease, (2) The inter gluteal crease in relation to the length central vertical mid buttock line. (3) The intergluteal crease and upper inner thigh angle, (4) The lower lateral gluteal with leg junction angle, (5) Mid lateral gluteal with hip junction angle, to determine if these angles are smooth, moderate or sharp demarcation as shown in Fig. (2).

\section{Lateral view:}

The following parameters were obtained; (a) outline curvature of buttocks, (b) Buttock projection at maximum projection point on curvature by measuring the mid vertical line of the buttock, (c) Determine the presence of ptosis and its grade through the amount fold present over the infragluteal crease if the fold doesn't exceed the crease, so there is no ptosis, if at the same level of the crease, so it is grade one ptosis, if exceeds the crease, so it is grade two and if exceeds to the level of the mid-leg, so it is grade three ptosis [9] As shown in Fig. (3).

Quantifying the pre-operative volume of gluteal region in each quadrant measured collectively for the whole buttock by using the ultrasound then compared to three and six months post-operatively. As shown in Fig. (4).

The right photo shows one quadrant of gluteal region pre-operatively; the yellow circle represents the subcutaneous plane (volume is $100 \mathrm{cc}$ ), while the orange one represents the intramuscular plane (volume is $150 \mathrm{cc}$.), the left photo shows the same quadrant following fat grafting; the yellow circle represents the subcutaneous plane (volume now is $200 \mathrm{cc})$ and the orange circle represents the intramuscular plane (volume now is $300 \mathrm{cc}$ ).

\section{Technique:}

Infiltration was performed by using superwet technique, infiltrating of the fat layer with a vasoconstrictive drug (adrenaline $0.001 \%$ ) Figs. $(5,6)$. 
Fat harvesting technique during liposuction was standardized using harvesting cannulas with $3 \mathrm{~mm}$ and $4 \mathrm{~mm}$ inner diameter attached to a suction machine (Byron with pressure one bar) and autoclavable jars. (Figs. 7,8).

Harvested fat left for 15 minute, and then the fluid in the bottom was suctioned through the cannula $2 \mathrm{~mm}$ and $50 \mathrm{cc}$ syringes.

\section{Fat grafting:}

Fat was collected in 50cc locked syringes, then injected into the four quadrants of the buttock according to the need of the patient by $2 \mathrm{~mm}$ cannula in a fan like pattern in three different planes deep (intramuscular), intermediate and superficial one (Fig. 10), then incisions were closed by vicryl 6/0 and at the end of the procedure the amount of fat injected in each quadrant was documented. Then the pressure garment was applied at the end of the operation.

Anthropometric measurements similar to those done pre-operatively were repeated three and six months postoperatively and compared with each other.

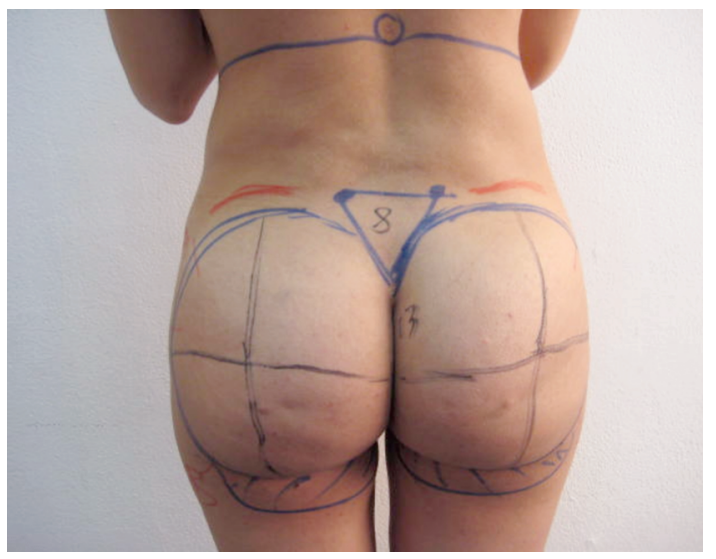

Fig. (1): Shows one of the control groups from posterior and lateral view.

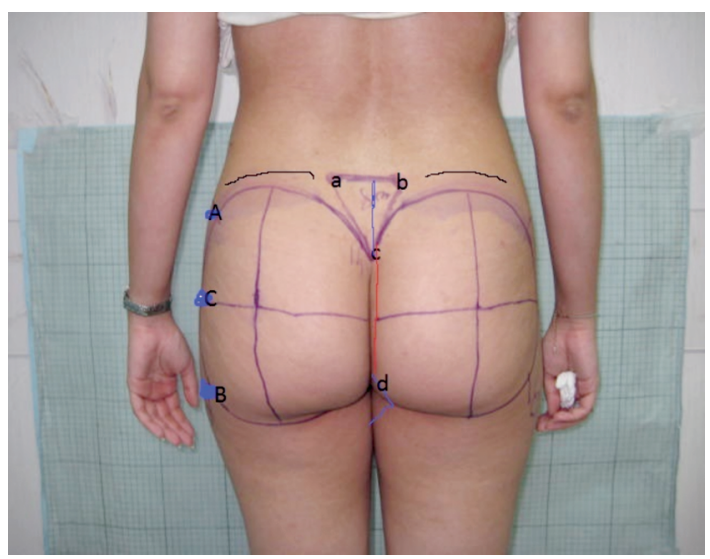

Fig. (2): Pre-operative markings in posterior view.

\section{Statistical analysis:}

Recorded data were analyzed using the statistical package for social sciences, version 20.0 (SPSS Inc., Chicago, Illinois, USA). Quantitative data were expressed as mean \pm standard deviation (SD). Qualitative data were expressed as frequency and percentage.

\section{The following tests were done:}

-A one-way analysis of variance (ANOVA) when comparing between more than two means.

- Chi-square $\left(\chi^{2}\right)$ test of significance was used in order to compare proportions between two qualitative parameters.

- The confidence interval was set to $95 \%$ and the margin of error accepted was set to $5 \%$. So, the $p$-value was considered significant as the following:

- Probability ( $p$-value).

- $p$-value $\leq 0.05$ was considered significant.

- $p$-value $\leq 0.001$ was considered as highly significant.

- $p$-value >0.05 was considered insignificant.

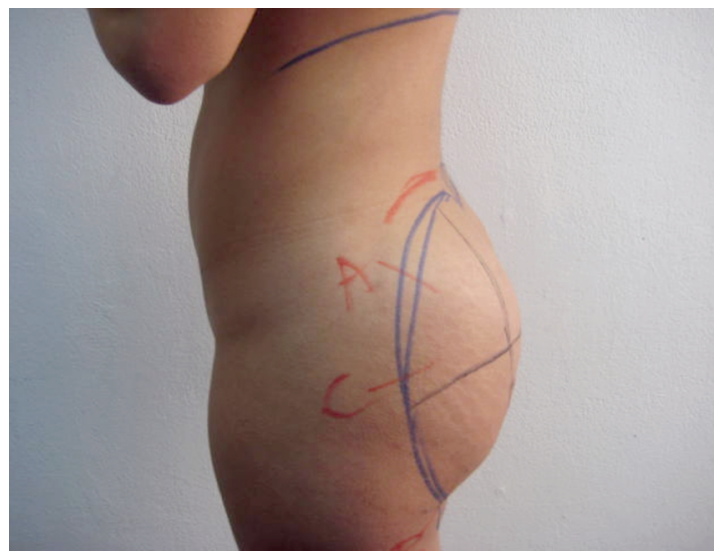



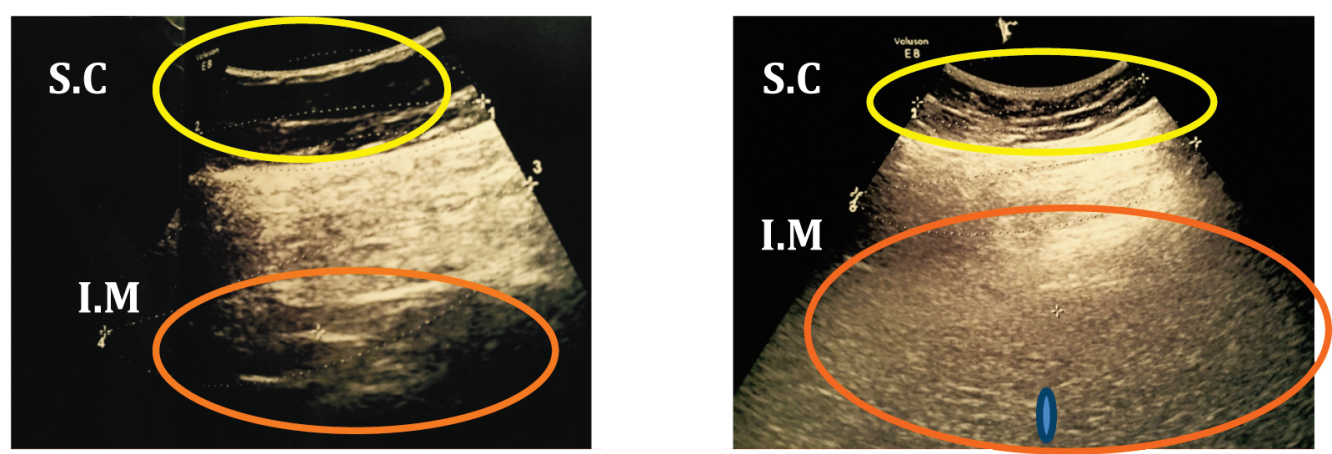

Fig. (4): Shows Ultrasound same gluteal area before and after fat grafting demonstrating an obvious increase in the white density which represents increase in the fat density.

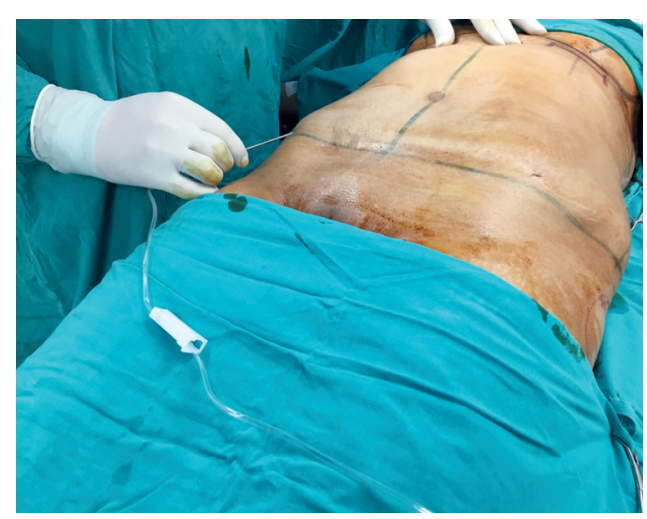

Fig. (5): Infiltration of the abdomen.

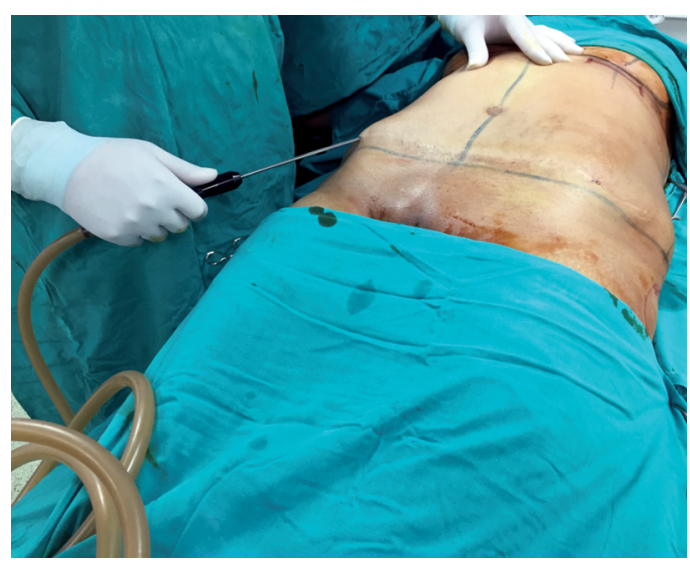

Fig. (7): Fat harvesting.

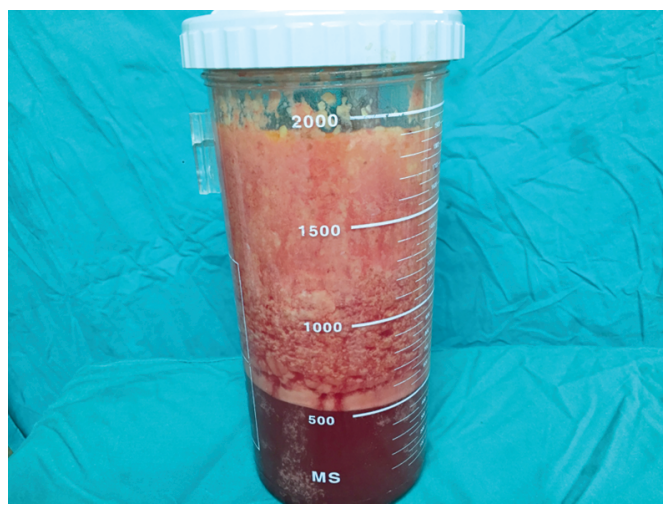

Fig. (9): Fat preparation after leaving it in the jar for 15 minutes.

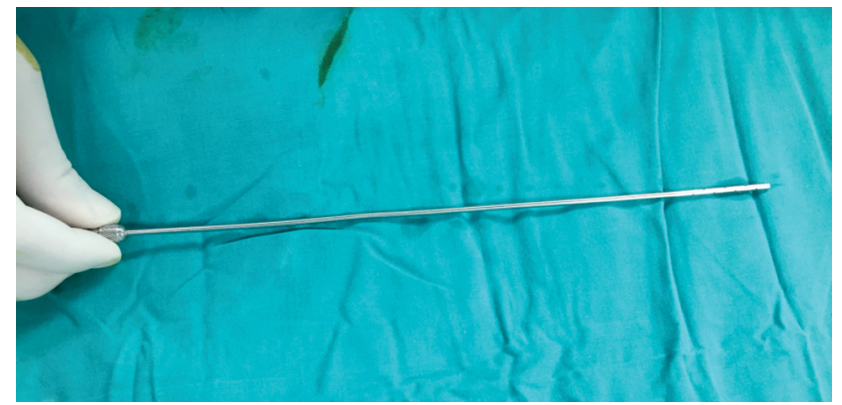

Fig. (6): Cannula of infiltration.

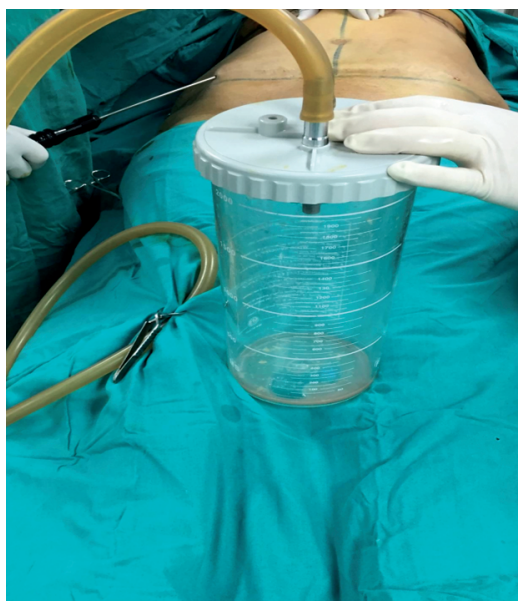

Fig. (8): Fat harvesting in the autoclavable jars.

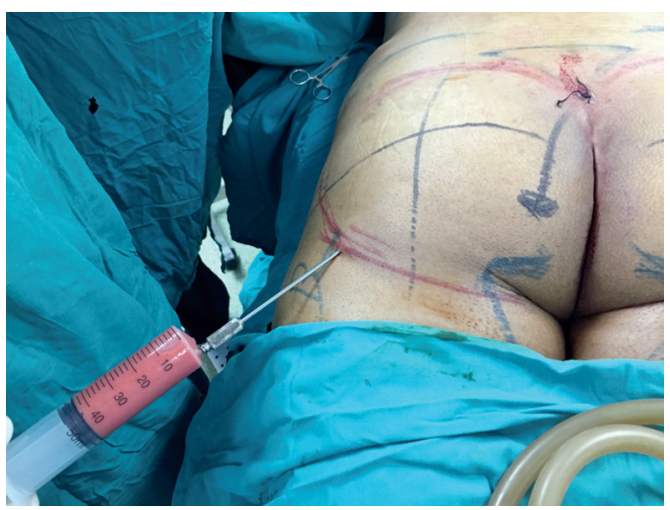

Fig. (10): Fat grafting in the buttock. 


\section{RESULTS}

Analysis of buttock shapes in the control group (30 candidates) showed that round shape buttocks was the dominant shape as shown in Fig. (11).

Anthropometry of the middle eastern (control group) characterizes by; sacral height measuring one third of the inter-gluteal crease, the intergluteal crease half of the mid vertical line of the buttock, the inter-gluteal crease with the upper inner thigh has downward slope, the lower lateral gluteal with leg junction (B) is natural (not depressed) and the mid lateral gluteal with hip junction (C) is also natural (not depressed) as shown in Fig. (12).

In group 1: Sacral height to inter gluteal crease was slightly decreased after 3 and 6 months postoperatively, while in group 2 moderate decrease in these measurements after 3 and more decrease at 6 months, but in group 3, there was great reduction in these measurements after 3 and 6 months post-operatively as shown in Table (1) and Fig. (13).

This table shows statistically significant difference between over the periods through sacral height to intergluteal crease in the group $2 \& 3$.

Intergluteal crease to mid vertical line of the buttock showed moderate increase at 3 and 6 months post-operatively in group 1 , while in group 2 there was slight decrease at 3 and 6 months postoperatively, but in group 3 there was slight increase 3 and 6 months post-operatively as shown in Table (2) and Fig. (14).

Downward slope was increased in all groups 3 and 6 months post-operatively, it showed 100\%

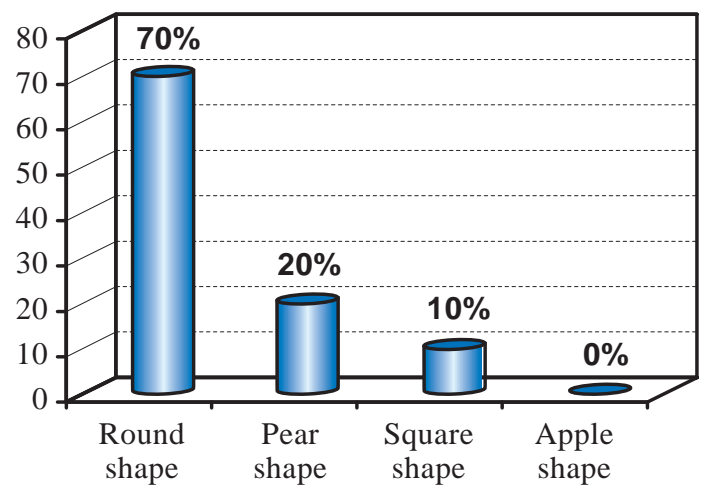

Fig. (11): Shows buttock shapes in control group. increase in group 1, 60\% increase in group 2, and $70 \%$ increase in group 3 as shown in Table (3) and Fig. (15).

Lower lateral gluteal with leg junction (B), in group one $90 \%$ became natural 3 months postoperatively and $100 \%$ at 6 months post-operatively, while in group two $80 \%$ of them became natural at 3 and 6 months post-operatively, while in group three $70 \%$ of them became natural 3 and 6 months post-operatively as shown in Table (4) and Fig. (16).

The mid lateral gluteal with hip junction (C) in group 1 was natural in 100\% 3 months and 6 months post-operatively, while in group 2 and 3 the results is natural in $90 \%$ at 3 and 6 months post-operatively as shown in Table (5) and Fig. (17).

This table shows statistically significant difference over the periods through mid-lateral gluteal with hip junction in the each group.

\section{Volume of fat grafting data analysis:}

The fat injected in the subcutaneous plane after three months showed reduction by $69 \%$ while in the intramuscular plane reduction was $88 \%$, so the fat injected in the intramuscular plane survives more than the subcutaneous plane.

The fat injected in the subcutaneous plane after three months decrease to $68 \%$, the same in group one while in the intramuscular plane to $88 \%$.

In this study a few complications have been occurred; asymmetry (one case), unilateral gluteal (one case) due to previous permanent filler injection two years before surgery.

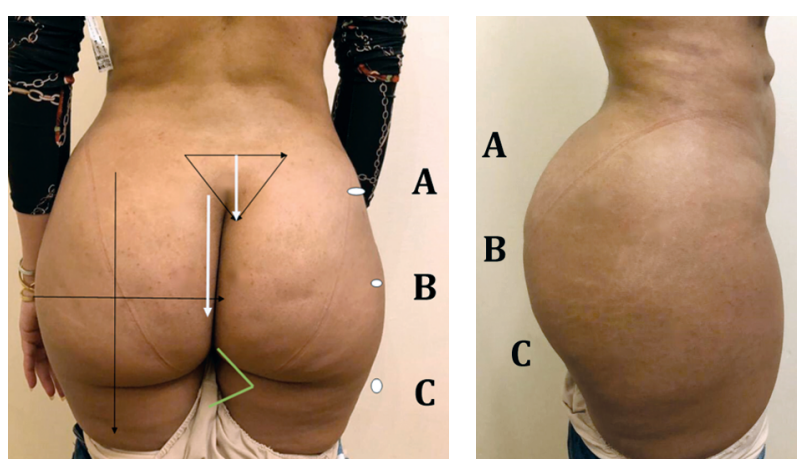

Fig. (12): Shows one case of the control group from posterior and lateral view. 


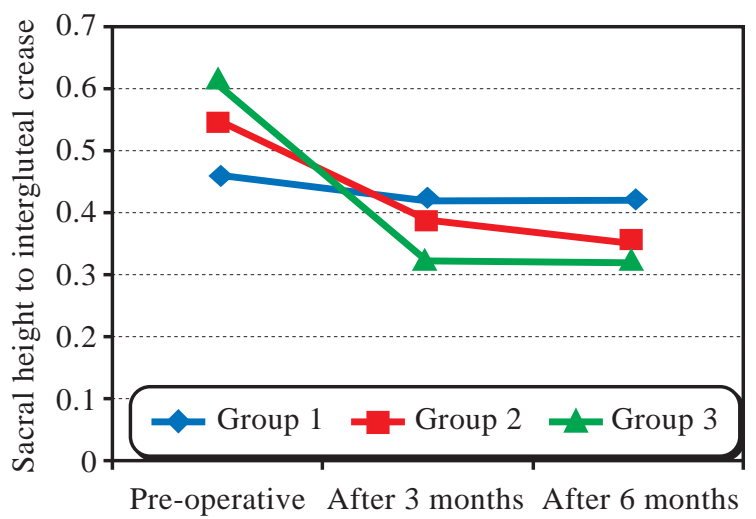

Fig. (13): Line the difference over the periods through sacral height to intergluteal crease in the each group.
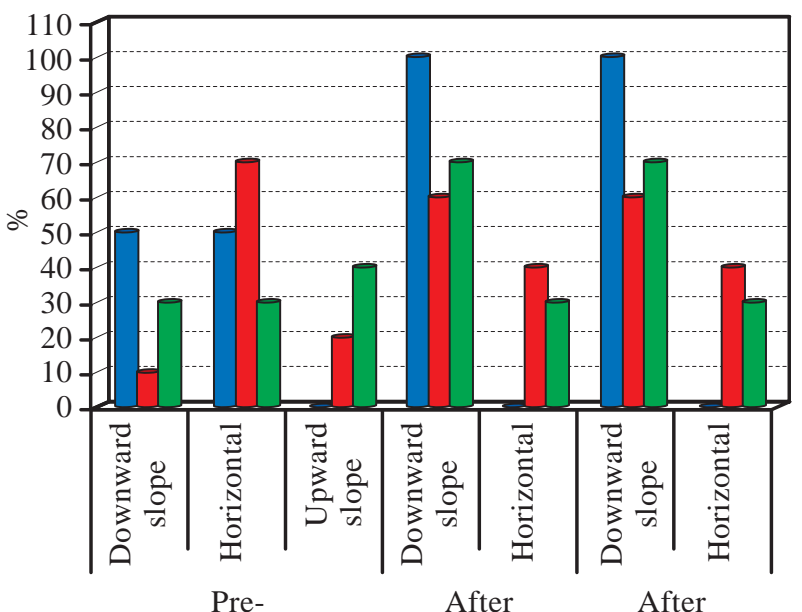

operative $\quad 3$ months 6 months

$\square$ Group $1 \square$ Group $2 \square$ Group 3

Fig. (15): Bar chart the difference over the periods through intergluteal crease with upper inner thigh in the each group.

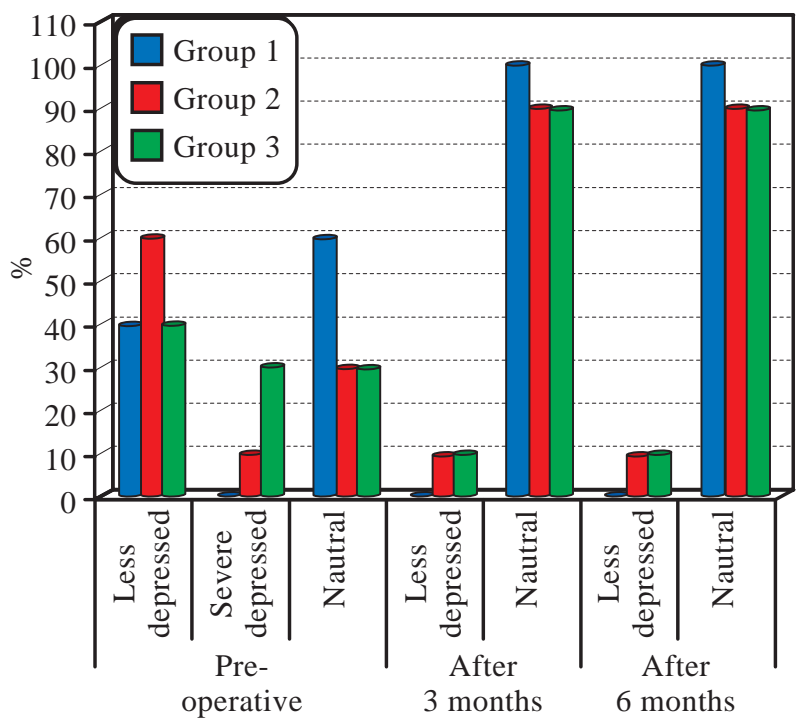

Fig. (17): Bar chart the difference over the periods through mid lateral gluteal with hip junction in the each group.

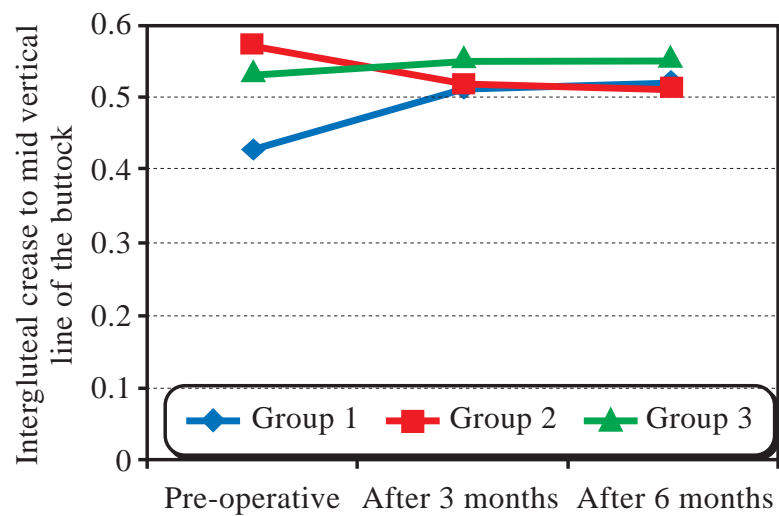

Fig. (14): Line the difference over the periods through intergluteal crease to mid vertical line of the buttock in the each group.

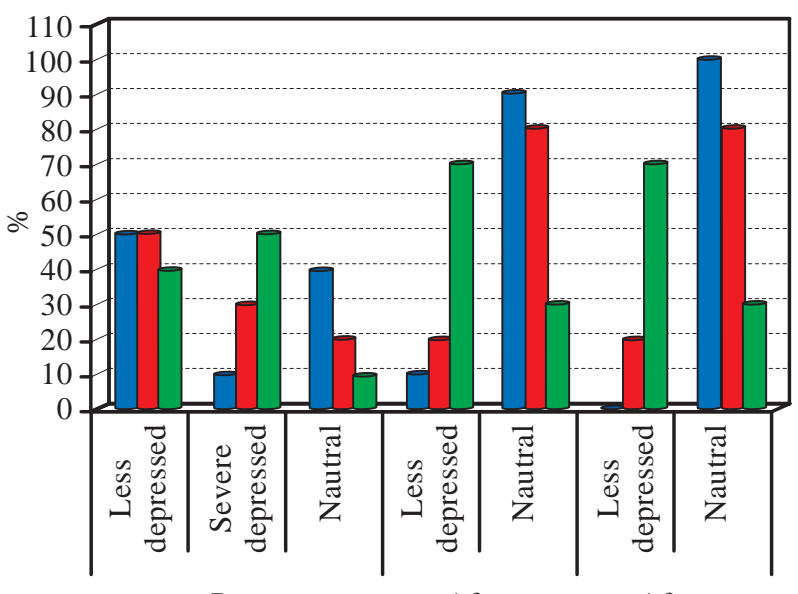

$$
\text { Pre- After After }
$$

operative $\quad 3$ months 6 months

$\square$ Group $1 \square$ Group $2 \square$ Group 3

Fig. (16): Bar chart the difference over the periods through lower lateral gluteal with leg junction (B) in the each group.

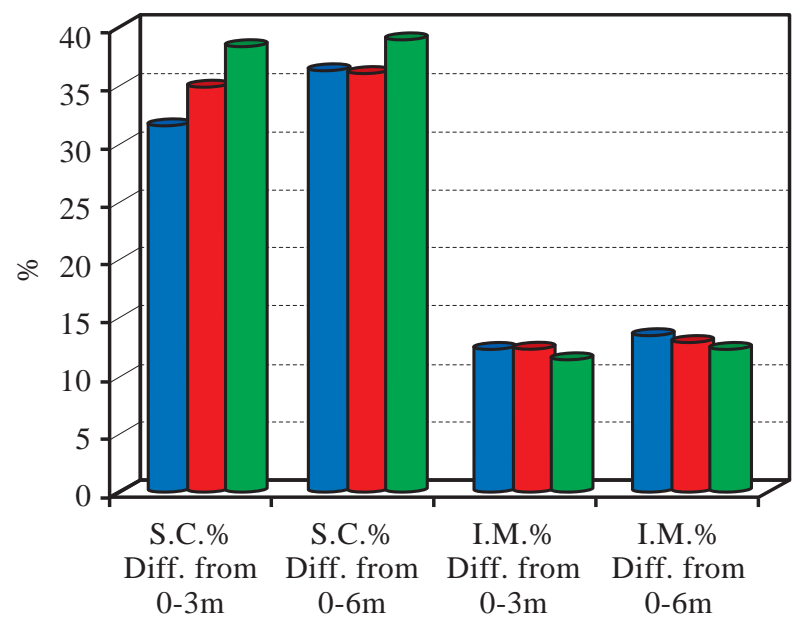

Group I $\square$ Group II $\square$ Group III

Fig. (18): Shows the mean difference of fat loss in both planes at preoperative, 3 and 6 months postoperative. 


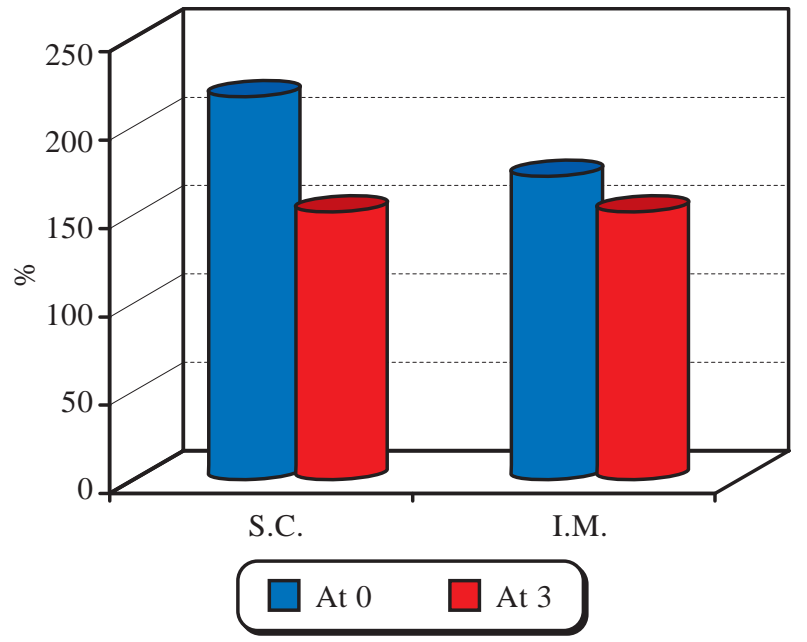

Fig. (19): Shows the difference between Zero and Three months according to Subcutaneous and intra muscular in group 1 .

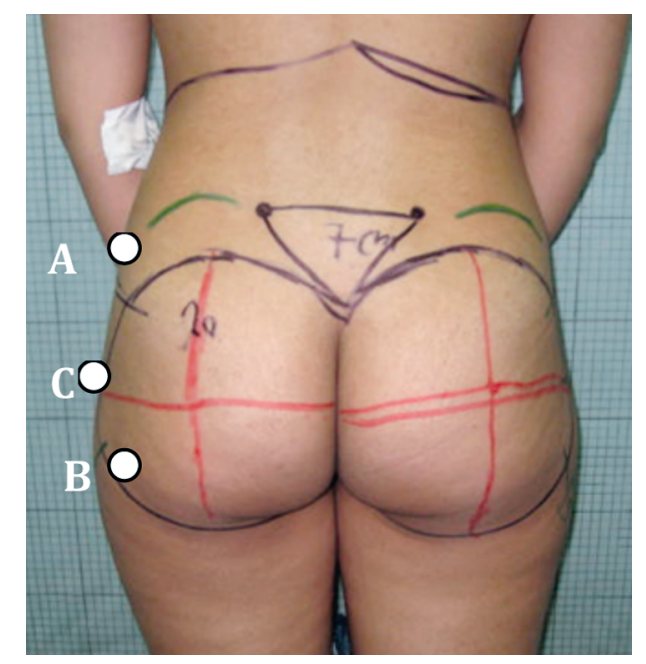

Fig. (21): Shows a patient from group 1 pre-operatively and 6 months post-operatively after fat grafting with $380 \mathrm{cc}$. in each side posterior view.
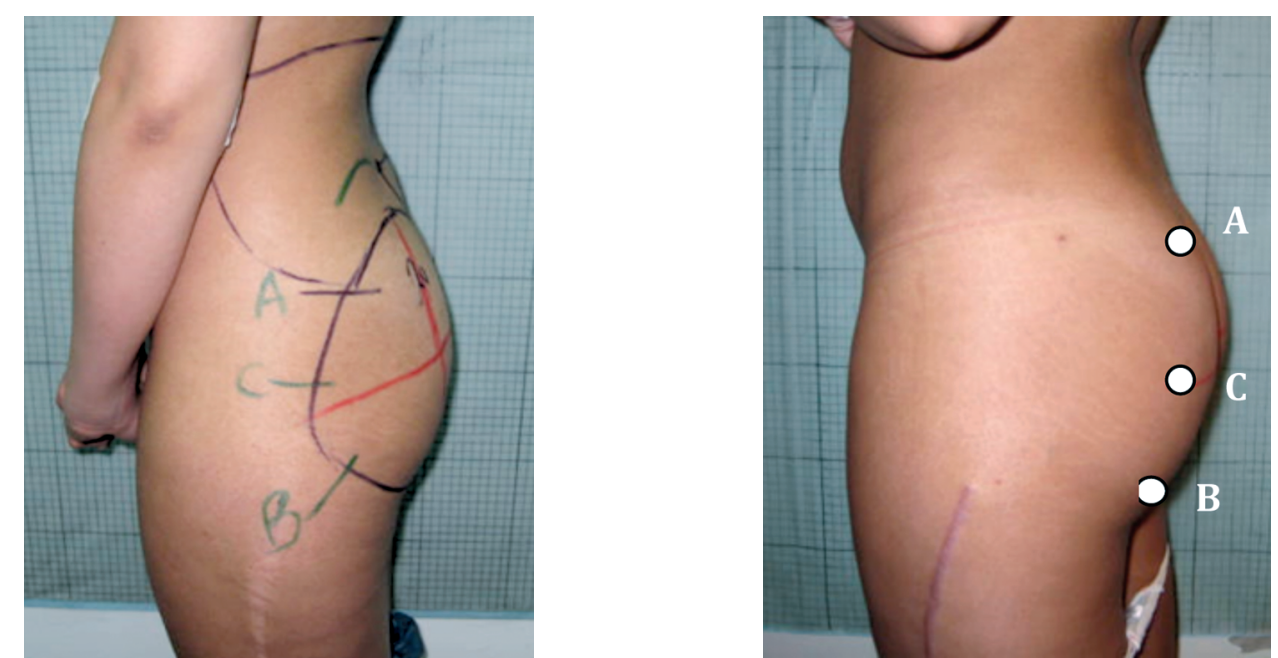

Fig. (22): Shows the same patient from lateral view. 

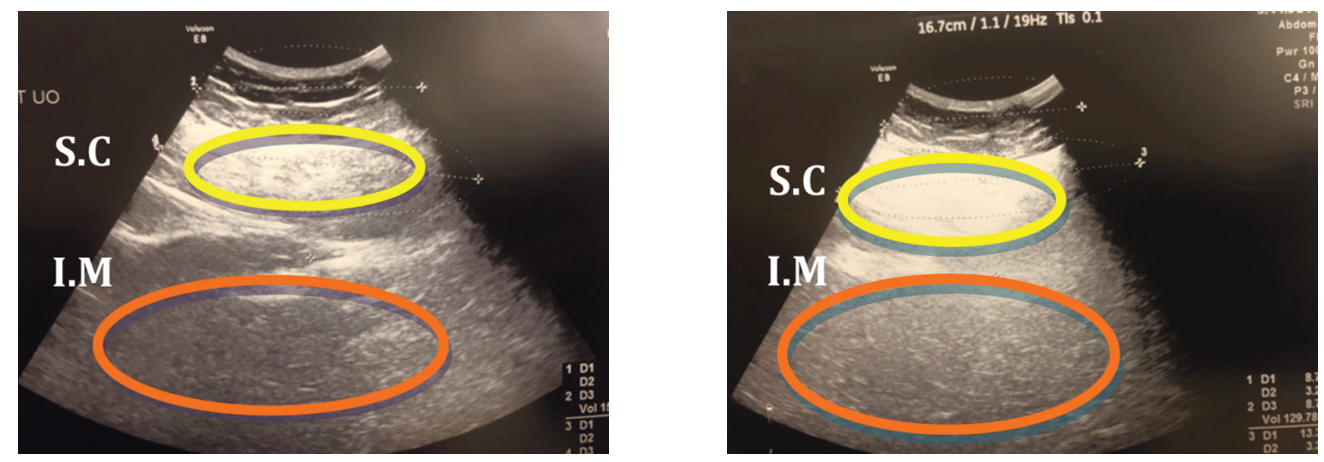

Fig. (23): Shows Ultrasound same gluteal area before and after fat grafting in group 1 six months post-operatively demonstrating an obvious increase in the white density which represent increase in the fat density.

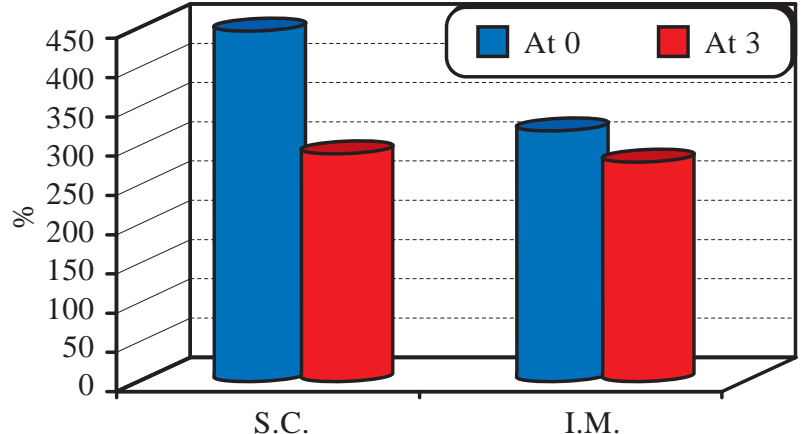

Fig. (24): Shows the difference between Zero and Three months according to Subcutaneous and intra muscular in group 2.

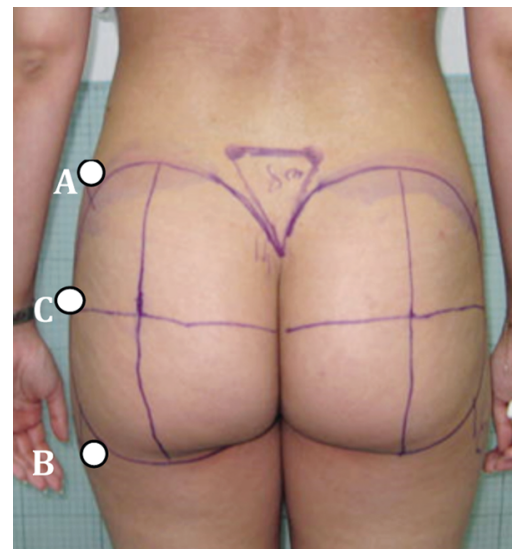

Fig. (26): Shows patient from group 2 pre-operatively and 3 months postoperatively after fat grafting with $750 \mathrm{cc}$ in each side of the buttock posterior view.

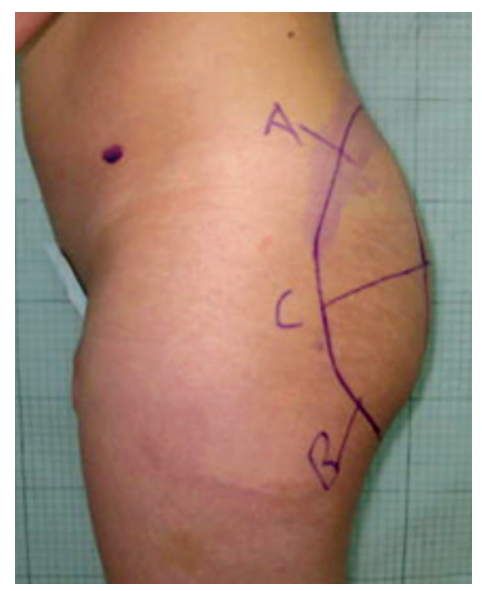

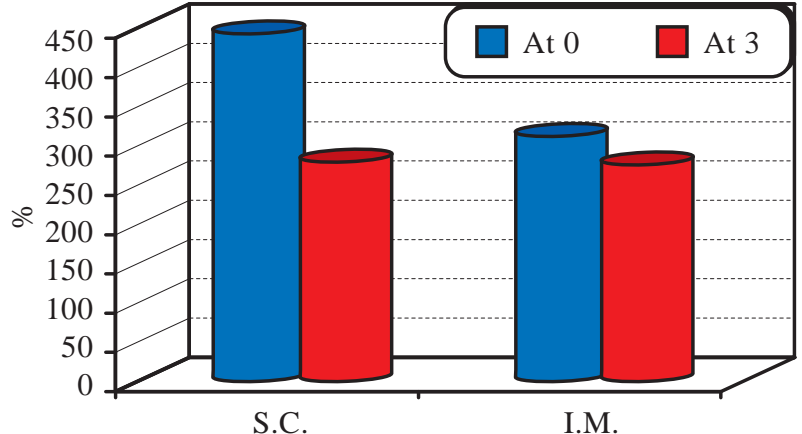

Fig. (25): Shows the difference between Zero and six months according to SC and IM in group 2.
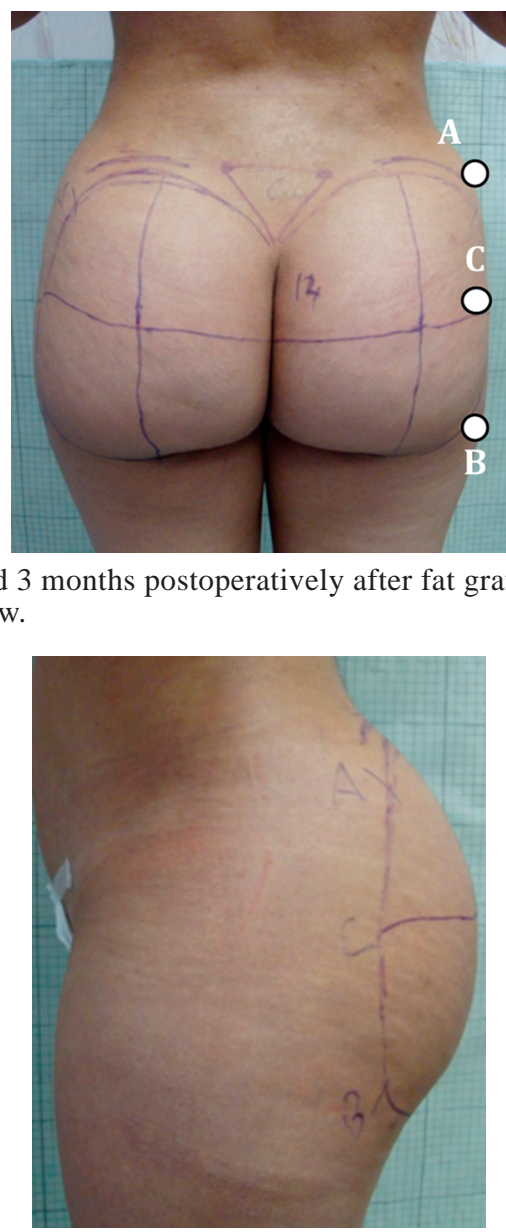

Fig. (27): Shows the same patient from lateral view. 

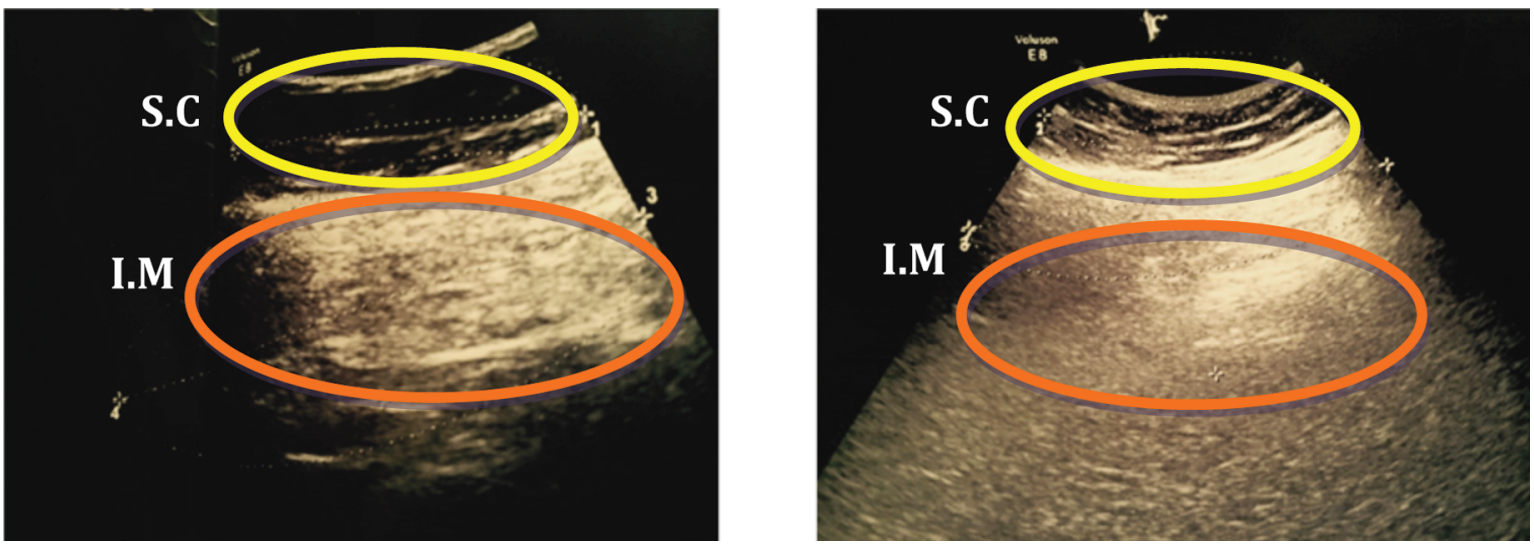

Fig. (28): Shows Ultrasound same gluteal area before and after fat grafting in group 2 six months postoperatively demonstrating an obvious increase in the white density which represent increase in the fat density.

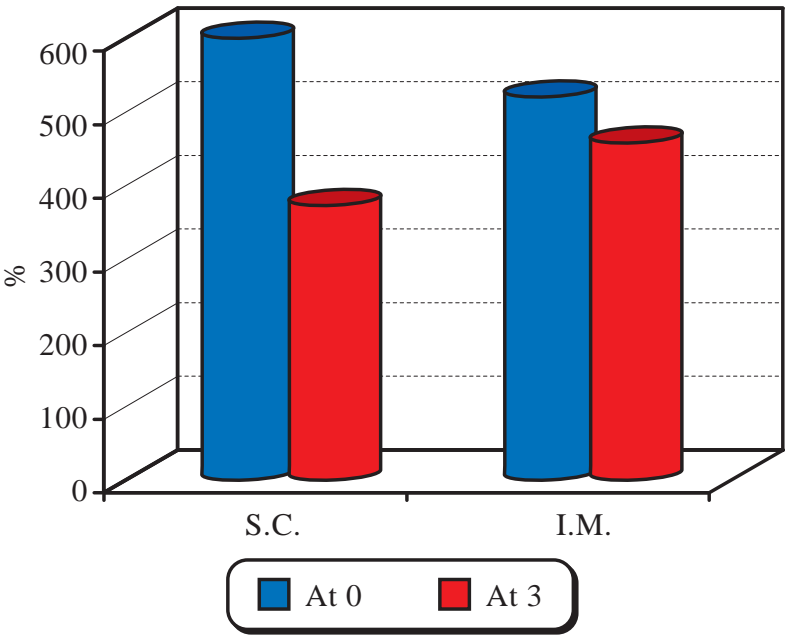

Fig. (29): Shows the difference between Zero and Three months according to Subcutaneous and intra muscular in group 3.
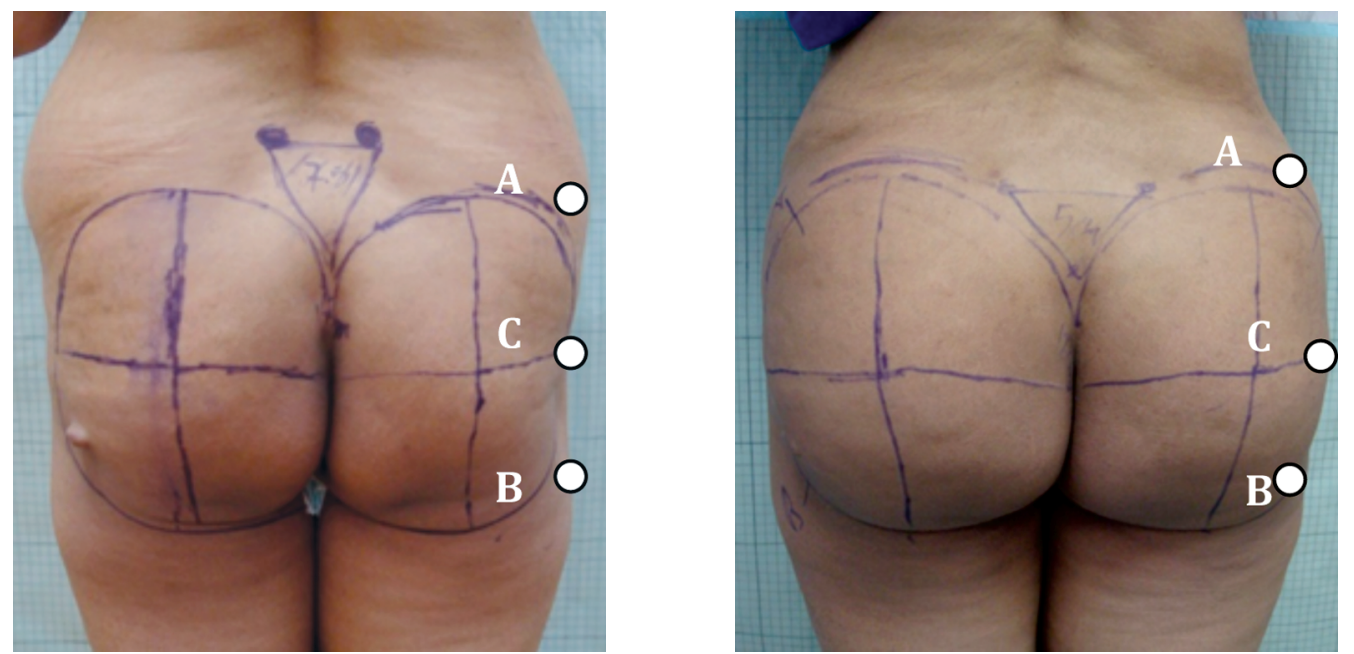

Fig. (31): Shows patient from group 3 pre-operatively and 6 months post-operatively after fat grafting with 900cc in each side of the buttock posterior view. 

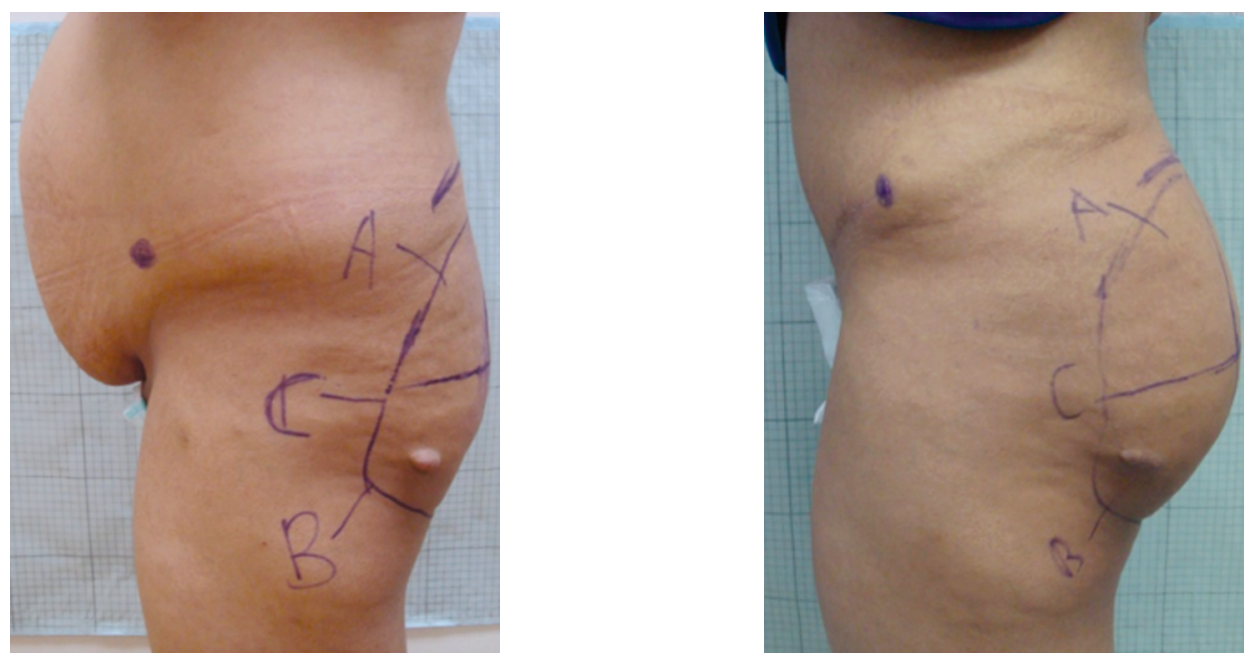

Fig. (32): Shows the same patient from lateral view.
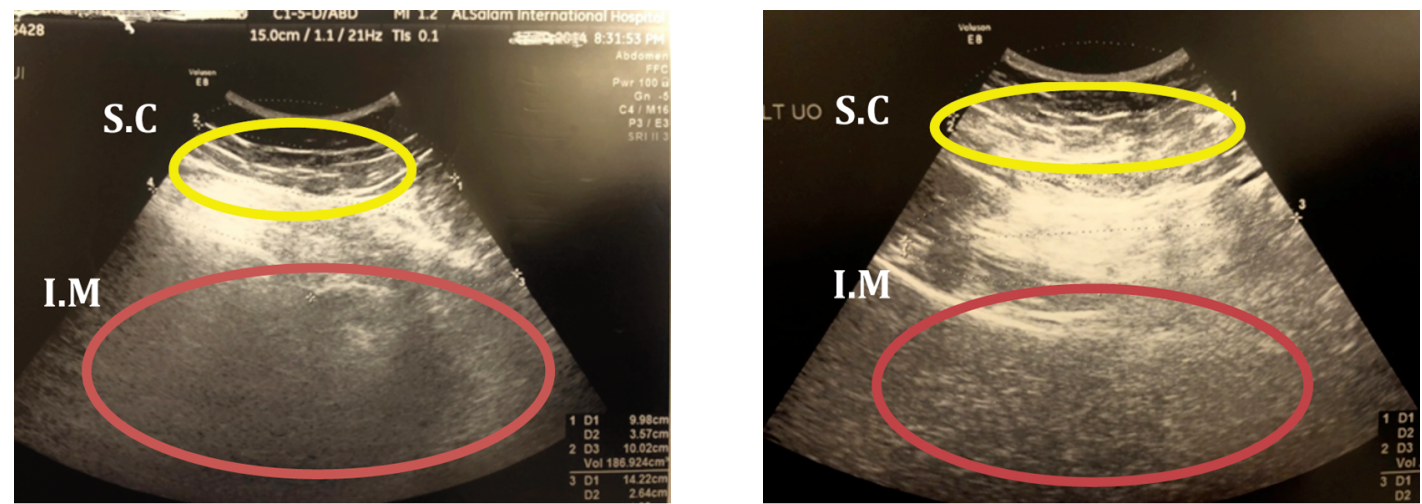

Fig. (33): Shows ultrasound same gluteal area before and after fat grafting in group 3 six months post-operatively demonstrating an obvious increase in the white density which represent increase in the fat density.

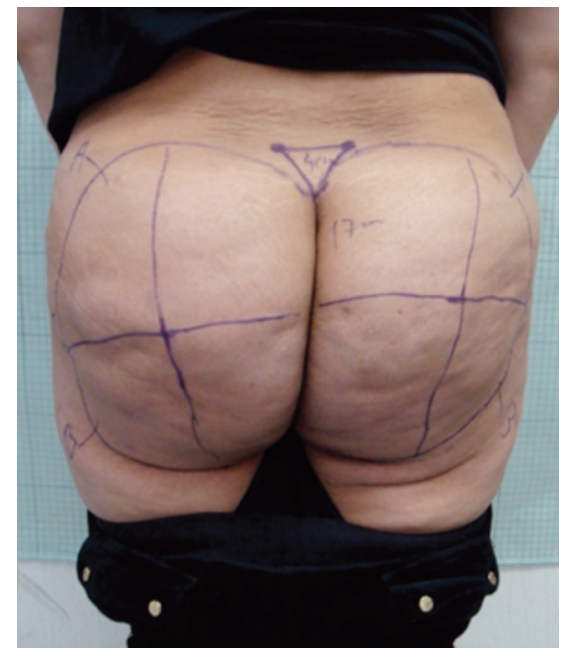

Fig. (34): Asymmetry.

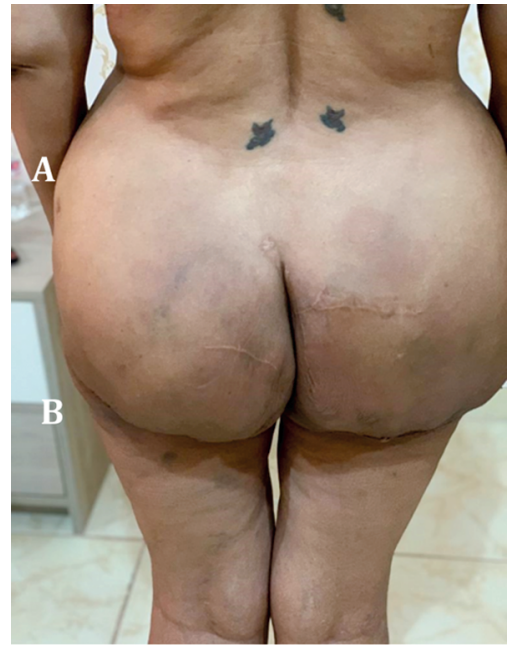

Fig. (35): Gluteal abscess. 
Table (1): The extent of the difference over the periods through sacral height to intergluteal crease in the each group.

\begin{tabular}{lllll}
$\begin{array}{l}\text { Sacral height } \\
\text { to intergluteal } \\
\text { crease }\end{array}$ & $\begin{array}{c}\text { Group 1 } \\
(\mathrm{N}=10)\end{array}$ & $\begin{array}{c}\text { Group 2 } \\
(\mathrm{N}=10)\end{array}$ & $\begin{array}{l}\text { Group 3 } \\
(\mathrm{N}=10)\end{array}$ & $\begin{array}{l}\text { Control } \\
(\mathrm{N}=10)\end{array}$ \\
\hline Pre-operative & $0.46 \pm 0.12$ & $0.55 \pm 0.10$ & $0.61 \pm 0.13$ & $0.27 \pm 0.05$ \\
After 3 months & $0.42 \pm 0.10$ & $0.39 \pm 0.14$ & $0.32 \pm 0.07$ & $0.27 \pm 0.05$ \\
After 6 months & $0.42 \pm 0.10$ & $0.35 \pm 0.13$ & $0.32 \pm 0.06$ & $0.27 \pm 0.05$ \\
ANOVA & 1.636 & 2.599 & 7.279 & 0.000 \\
$p$-value & 0.138 & $0.029 *$ & $<0.001 * *$ & 1.000 \\
\hline
\end{tabular}

Table (2): The extent of the difference over the periods through intergluteal crease to mid vertical line of the buttock in the each group.

\begin{tabular}{lllll}
\hline $\begin{array}{l}\text { Intergluteal crease } \\
\begin{array}{l}\text { to mid vertical } \\
\text { line of the buttock }\end{array}\end{array}$ & $\begin{array}{l}\text { Group 1 } \\
(\mathrm{N}=10)\end{array}$ & $\begin{array}{l}\text { Group 2 } \\
(\mathrm{N}=10)\end{array}$ & $\begin{array}{l}\text { Group 3 } \\
(\mathrm{N}=10)\end{array}$ & $\begin{array}{l}\text { Control } \\
(\mathrm{N}=10)\end{array}$ \\
\hline Pre-operative & $0.43 \pm 0.05$ & $0.57 \pm 0.10$ & $0.53 \pm 0.07$ & $0.52 \pm 0.05$ \\
After 3 months & $0.51 \pm 0.06$ & $0.52 \pm 0.04$ & $0.55 \pm 0.07$ & $0.52 \pm 0.05$ \\
After 6 months & $0.52 \pm 0.03$ & $0.51 \pm 0.03$ & $0.55 \pm 0.06$ & $0.52 \pm 0.05$ \\
ANOVA & 3.979 & 1.728 & 0.994 & 0.000 \\
$p$-value & $0.003 *$ & 0.118 & 0.346 & 1.000 \\
\hline
\end{tabular}

Table (3): The extent of the difference over the periods through intergluteal crease with upper inner thigh in the each group.

\begin{tabular}{|c|c|c|c|c|}
\hline $\begin{array}{l}\text { Intergluteal } \\
\text { crease with } \\
\text { upper inner } \\
\text { thigh }\end{array}$ & $\begin{array}{l}\text { Group } 1 \\
(\mathrm{~N}=10)\end{array}$ & $\begin{array}{l}\text { Group } 2 \\
(\mathrm{~N}=10)\end{array}$ & $\begin{array}{c}\text { Group } 3 \\
(\mathrm{~N}=10)\end{array}$ & $\begin{array}{l}\text { Control } \\
(\mathrm{N}=10)\end{array}$ \\
\hline \multicolumn{5}{|l|}{ Pre-operative: } \\
\hline $\begin{array}{l}\text { Downward } \\
\text { slope }\end{array}$ & $5(50.0 \%)$ & $1(10.0 \%)$ & $3(30.0 \%)$ & $30(100.0 \%)$ \\
\hline Horizontal & $5(50.0 \%)$ & $7(70.0 \%)$ & $3(30.0 \%)$ & $0(0.0 \%)$ \\
\hline Upward slope & $0(0.0 \%)$ & $2(20.0 \%)$ & $4(40.0 \%)$ & $0(0.0 \%)$ \\
\hline \multicolumn{5}{|l|}{ After 3 months: } \\
\hline $\begin{array}{l}\text { Downward } \\
\text { slope }\end{array}$ & $10(100.0 \%)$ & $6(60.0 \%)$ & $7(70.0 \%)$ & $30(100.0 \%)$ \\
\hline Horizontal & $0(0.0 \%)$ & $4(40.0 \%)$ & $3(30.0 \%)$ & $0(0.0 \%)$ \\
\hline Upward slope & $0(0.0 \%)$ & $0(0.0 \%)$ & $0(0.0 \%)$ & $0(0.0 \%)$ \\
\hline \multicolumn{5}{|l|}{ After 6 months: } \\
\hline $\begin{array}{l}\text { Downward } \\
\text { slope }\end{array}$ & $10(100.0 \%)$ & $6(60.0 \%)$ & $7(70.0 \%)$ & $30(100.0 \%)$ \\
\hline Horizontal & $0(0.0 \%)$ & $4(40.0 \%)$ & $3(30.0 \%)$ & $0(0.0 \%)$ \\
\hline Upward slope & $0(0.0 \%)$ & $0(0.0 \%)$ & $0(0.0 \%)$ & $0(0.0 \%)$ \\
\hline Chi-square test & 12.683 & 9.046 & 9.882 & 0.000 \\
\hline$p$-value & $0.003 *$ & $0.049 *$ & $0.043 *$ & 1.000 \\
\hline
\end{tabular}

Table (4): The extent of the difference over the periods through lower lateral gluteal with leg junction (B) in the each group.

\begin{tabular}{|c|c|c|c|c|}
\hline $\begin{array}{l}\text { Lower lateral } \\
\text { gluteal with } \\
\text { leg junction(B) }\end{array}$ & $\begin{array}{l}\text { Group 1 } \\
(\mathrm{N}=10)\end{array}$ & $\begin{array}{l}\text { Group } 2 \\
(\mathrm{~N}=10)\end{array}$ & $\begin{array}{c}\text { Group } 3 \\
(\mathrm{~N}=10)\end{array}$ & $\begin{array}{l}\text { Control } \\
(\mathrm{N}=10)\end{array}$ \\
\hline \multicolumn{5}{|l|}{ Pre-operative: } \\
\hline Less depressed & $5(50.0 \%)$ & $5(50.0 \%)$ & $4(40.0 \%)$ & $0(0.0 \%)$ \\
\hline $\begin{array}{l}\text { Severe } \\
\text { depressed }\end{array}$ & $1(10.0 \%)$ & $3(30.0 \%)$ & $5(50.0 \%)$ & $0(0.0 \%)$ \\
\hline Natural & $4(40.0 \%)$ & $2(20.0 \%)$ & $1(10.0 \%)$ & $30(100.0 \%)$ \\
\hline \multicolumn{5}{|l|}{ After 3 months: } \\
\hline Less depressed & $1(10.0 \%)$ & $2(20.0 \%)$ & $7(70.0 \%)$ & $0(0.0 \%)$ \\
\hline $\begin{array}{l}\text { Severe } \\
\text { depressed }\end{array}$ & $0(0.0 \%)$ & $0(0.0 \%)$ & $0(0.0 \%)$ & $0(0.0 \%)$ \\
\hline Natural & $9(90.0 \%)$ & $8(80.0 \%)$ & $3(30.0 \%)$ & $30(100.0 \%)$ \\
\hline \multicolumn{5}{|l|}{ After 6 months: } \\
\hline Less depressed & $0(0.0 \%)$ & $2(20.0 \%)$ & $7(70.0 \%)$ & $0(0.0 \%)$ \\
\hline $\begin{array}{l}\text { Severe } \\
\text { depressed }\end{array}$ & $0(0.0 \%)$ & $0(0.0 \%)$ & $0(0.0 \%)$ & $0(0.0 \%)$ \\
\hline Natural & $10(100.0 \%)$ & $8(80.0 \%)$ & $3(30.0 \%)$ & $30(100.0 \%)$ \\
\hline Chi-square test & 22.300 & 8.632 & 3.727 & 0.000 \\
\hline$p$-value & $<0.001 * *$ & 0.071 & 0.444 & 1.000 \\
\hline
\end{tabular}

Table (5): The extent of the difference over the periods through mid lateral gluteal with hip junction in the each group.

\begin{tabular}{|c|c|c|c|c|}
\hline $\begin{array}{l}\text { Mid lateral } \\
\text { gluteal with } \\
\text { hip junction(C) }\end{array}$ & $\begin{array}{c}\text { Group } 1 \\
(\mathrm{~N}=10)\end{array}$ & $\begin{array}{c}\text { Group } 2 \\
(\mathrm{~N}=10)\end{array}$ & $\begin{array}{c}\text { Group } 3 \\
(\mathrm{~N}=10)\end{array}$ & $\begin{array}{l}\text { Control } \\
(\mathrm{N}=10)\end{array}$ \\
\hline \multicolumn{5}{|l|}{ Pre-operative: } \\
\hline Less depressed & $4(40.0 \%)$ & $6(60.0 \%)$ & $4(40.0 \%)$ & $0(0.0 \%)$ \\
\hline $\begin{array}{l}\text { Severe } \\
\text { depressed }\end{array}$ & $0(0.0 \%)$ & $1(10.0 \%)$ & $3(30.0 \%)$ & $0(0.0 \%)$ \\
\hline Natural & $6(60.0 \%)$ & $3(30.0 \%)$ & $3(30.0 \%)$ & $30(100.0 \%)$ \\
\hline \multicolumn{5}{|l|}{ After 3 months: } \\
\hline Less depressed & $0(0.0 \%)$ & $1(10.0 \%)$ & $1(10.0 \%)$ & $0(0.0 \%)$ \\
\hline $\begin{array}{l}\text { Severe } \\
\text { depressed }\end{array}$ & $0(0.0 \%)$ & $0(0.0 \%)$ & $0(0.0 \%)$ & $0(0.0 \%)$ \\
\hline Natural & $10(100.0 \%)$ & $9(90.0 \%)$ & $9(90.0 \%)$ & $30(100.0 \%)$ \\
\hline \multicolumn{5}{|l|}{ After 6 months: } \\
\hline Less depressed & $0(0.0 \%)$ & $1(10.0 \%)$ & $1(10.0 \%)$ & $0(0.0 \%)$ \\
\hline $\begin{array}{l}\text { Severe } \\
\text { depressed }\end{array}$ & $0(0.0 \%)$ & $0(0.0 \%)$ & $0(0.0 \%)$ & $0(0.0 \%)$ \\
\hline Natural & $10(100.0 \%)$ & $9(90.0 \%)$ & $9(90.0 \%)$ & $30(100.0 \%)$ \\
\hline Chi-square test & 30.004 & 18.987 & 12.429 & 0.000 \\
\hline$p$-value & $<0.001 * *$ & $<0.001 * *$ & $0.014^{*}$ & 1.000 \\
\hline
\end{tabular}

Table (6): Volume of fat grafting descriptive in each group.

\begin{tabular}{llll}
$\begin{array}{l}\text { Volume of } \\
\text { fat injection }\end{array}$ & $\begin{array}{c}\text { Group 1 } \\
(\mathrm{N}=10)\end{array}$ & $\begin{array}{c}\text { Group 2 } \\
(\mathrm{N}=10)\end{array}$ & $\begin{array}{c}\text { Group 3 } \\
(\mathrm{N}=10)\end{array}$ \\
\hline $\begin{array}{l}\text { Volume of fat } \\
\text { injection in }\end{array}$ & & & \\
$\begin{array}{l}\text { S.C plane: } \\
\quad \text { Mean } \pm \mathrm{SD}\end{array}$ & $217.00 \pm 70.72$ & $445.00 \pm 127.91$ & $600.00 \pm 184.09$ \\
$\quad$ Range & $150-400$ & $250-700$ & $300-1000$ \\
$\begin{array}{l}\text { Volume of fat } \\
\text { injection in }\end{array}$ & & & \\
$\begin{array}{l}\text { MS plane: } \\
\quad \text { Mean } \pm \mathrm{SD}\end{array}$ & $172.22 \pm 36.32$ & $316.67 \pm 82.92$ & $520.00 \pm 147.57$ \\
$\quad$ Range & $100-200$ & $200-400$ & $300-800$
\end{tabular}

Data represented as Mean $\pm \mathrm{SD}$. 
Table (7): Shows the mean difference of fat loss in both planes at preoperative, 3 and 6 months postoperative.

\begin{tabular}{|c|c|c|c|c|c|}
\hline Volume of fat injection & Group I & Group II & Group II & ANOVA & $p$-value \\
\hline $\begin{array}{l}\text { S.C } 0: \\
\quad \text { Mean } \pm \mathrm{SD} \\
\text { Range }\end{array}$ & $\begin{array}{l}217.00 \pm 70.72 \\
150-400\end{array}$ & $\begin{array}{l}445.00 \pm 127.91 \\
250-700\end{array}$ & $\begin{array}{l}600.00 \pm 184.09 \\
300-1000\end{array}$ & 20.153 & $<0.001 * *$ \\
\hline $\begin{array}{l}\text { S.C 3: } \\
\text { Mean } \pm \text { SD } \\
\text { Range }\end{array}$ & $\begin{array}{l}151.00 \pm 62.80 \\
100-300\end{array}$ & $\begin{array}{l}290.71 \pm 110.49 \\
150-450\end{array}$ & $\begin{array}{l}372.00 \pm 176.09 \\
125-700\end{array}$ & 9.273 & $<0.001 * *$ \\
\hline $\begin{array}{l}\text { Diff. from } 0-3 \% \text { : } \\
\text { Mean } \pm \text { SD } \\
\text { Range }\end{array}$ & $\begin{array}{l}31.44 \pm 10.69 \\
15-50\end{array}$ & $\begin{array}{l}34.67 \pm 13.18 \\
11.11-70\end{array}$ & $\begin{array}{l}38.08 \pm 21.46 \\
10-75\end{array}$ & 1.054 & 0.396 \\
\hline $\begin{array}{l}\text { S.C 6: } \\
\quad \text { Mean } \pm \text { SD } \\
\text { Range }\end{array}$ & $\begin{array}{l}138.50 \pm 46.55 \\
100-250\end{array}$ & $\begin{array}{l}282.42 \pm 101.65 \\
150-450\end{array}$ & $\begin{array}{l}367.00 \pm 175.91 \\
125-700\end{array}$ & 10.646 & $<0.001 * *$ \\
\hline $\begin{array}{l}\text { Diff. from 0-6\%: } \\
\text { Mean } \pm \text { SD } \\
\text { Range }\end{array}$ & $\begin{array}{l}36.10 \pm 6.95 \\
25-50\end{array}$ & $\begin{array}{l}35.84 \pm 13.62 \\
12.5-70\end{array}$ & $\begin{array}{l}38.92 \pm 21.42 \\
10-75\end{array}$ & 0.915 & 0.446 \\
\hline $\begin{array}{l}\text { I.M O: } \\
\quad \text { Mean } \pm \text { SD } \\
\text { Range }\end{array}$ & $\begin{array}{l}172.22 \pm 36.32 \\
100-200\end{array}$ & $\begin{array}{l}316.67 \pm 82.92 \\
200-400\end{array}$ & $\begin{array}{l}520.00 \pm 147.57 \\
300-800\end{array}$ & 23.642 & $<0.001 * *$ \\
\hline $\begin{array}{l}\text { I.M 3: } \\
\quad \text { Mean } \pm \text { SD } \\
\text { Range }\end{array}$ & $\begin{array}{l}151.11 \pm 34.89 \\
90-190\end{array}$ & $\begin{array}{l}277.44 \pm 78.12 \\
170-380\end{array}$ & $\begin{array}{l}460.00 \pm 144.43 \\
275-700\end{array}$ & 19.72 & $<0.001 * *$ \\
\hline $\begin{array}{l}\text { Diff. from 0-3\%: } \\
\text { Mean } \pm \text { SD } \\
\text { Range }\end{array}$ & $\begin{array}{l}12.31 \pm 6.12 \\
5-25\end{array}$ & $\begin{array}{l}12.39 \pm 4.71 \\
5-15\end{array}$ & $\begin{array}{l}11.50 \pm 11.63 \\
0-40\end{array}$ & 0.227 & 0.885 \\
\hline $\begin{array}{l}\text { I.M 6: } \\
\quad \text { Mean } \pm \text { SD } \\
\text { Range }\end{array}$ & $\begin{array}{l}148.89 \pm 32.67 \\
90-190\end{array}$ & $\begin{array}{l}277.78 \pm 81.36 \\
160-380\end{array}$ & $\begin{array}{l}455.00 \pm 139.84 \\
275-700\end{array}$ & 23.695 & $<0.001 * *$ \\
\hline $\begin{array}{l}\text { Diff. from 0-6\%: } \\
\text { Mean } \pm \text { SD } \\
\text { Range }\end{array}$ & $\begin{array}{l}13.43 \pm 5.50 \\
5-25\end{array}$ & $\begin{array}{l}12.90 \pm 4.91 \\
5-20\end{array}$ & $\begin{array}{l}12.27 \pm 11.61 \\
0-40\end{array}$ & 0.049 & 0.953 \\
\hline
\end{tabular}

Table (8): Shows statistically significant difference between Zero and Three months according to Subcutaneous and intra muscular in group 1.

\begin{tabular}{lcccc}
\hline & Group I & $\begin{array}{c}\text { Diff. from } \\
0-3 \%\end{array}$ & $\begin{array}{c}\text { Paired } \\
\text { sample } t \text {-test }\end{array}$ & $p$-value \\
\hline S.C 0 & $217.00 \pm 70.72$ & & & \\
S.C 3 & $151.00 \pm 62.80$ & $31.44 \pm 10.69$ & 2.207 & $0.041^{*}$ \\
I.M 0 & $172.22 \pm 36.32$ & & & \\
I.M 3 & $151.11 \pm 34.89$ & $12.31 \pm 6.12$ & 1.325 & 0.211 \\
\hline
\end{tabular}

Table (9): Shows statistically significant difference between Zero and six months according to SC and IM in group 1 .

\begin{tabular}{lcccc}
\hline & Group I & $\begin{array}{c}\text { Diff. from } \\
0-6 \%\end{array}$ & $\begin{array}{c}\text { Paired } \\
\text { sample } t \text {-test }\end{array}$ & $p$-value \\
\hline S.C 0 & $217.00 \pm 70.72$ & & & \\
S.C 6 & $138.50 \pm 46.55$ & $36.10 \pm 6.95$ & 2.932 & $0.009 *$ \\
I.M 0 & $172.22 \pm 36.32$ & & & \\
I.M 6 & $148.89 \pm 32.67$ & $13.43 \pm 5.50$ & 1.510 & 0.148 \\
\hline
\end{tabular}

Table (10): Shows statistically significant difference between Zero and Three months according to Subcutaneous and intra muscular in group 2.

\begin{tabular}{lcccc}
\hline & Group II & $\begin{array}{c}\text { Diff. from } \\
0-3 \%\end{array}$ & $\begin{array}{c}\text { Paired } \\
\text { sample } t \text {-test }\end{array}$ & $p$-value \\
\hline S.C 0 & $445.00 \pm 127.91$ & & & \\
S.C 3 & $290.71 \pm 110.49$ & $34.67 \pm 13.18$ & 2.887 & $0.009^{*}$ \\
I.M 0 & $316.67 \pm 82.92$ & & & \\
I.M 3 & $277.44 \pm 78.12$ & $12.39 \pm 4.71$ & 1.089 & 0.291 \\
\hline
\end{tabular}

Table (11): Shows statistically significant difference between Zero and six months according to SC and IM in group 2 .

\begin{tabular}{lcccc}
\hline & Group II & $\begin{array}{c}\text { Diff. from } \\
0-6 \%\end{array}$ & $\begin{array}{c}\text { Paired } \\
\text { sample } t \text {-test }\end{array}$ & $p$-value \\
\hline S.C 0 & $445.00 \pm 127.91$ & & & \\
S.C 6 & $282.42 \pm 101.65$ & $35.84 \pm 13.62$ & 3.147 & $0.006^{*}$ \\
I.M 0 & $316.67 \pm 82.92$ & & & \\
I.M 6 & $277.78 \pm 81.36$ & $12.90 \pm 4.91$ & 1.059 & 0.304 \\
\hline
\end{tabular}


Table (12): Shows statistically significant difference between Zero and Three months according to subcutaneous and intra muscular in group 3.

\begin{tabular}{lcccc}
\hline & Group III & $\begin{array}{c}\text { Diff. from } \\
0-3 \%\end{array}$ & $\begin{array}{c}\text { Paired } \\
\text { sample } t \text {-test }\end{array}$ & $p$-value \\
\hline S.C 0 & $600.00 \pm 184.09$ & & & \\
S.C 3 & $372.00 \pm 176.09$ & $38.08 \pm 21.46$ & 2.832 & $0.011^{*}$ \\
I.M 0 & $520.00 \pm 147.57$ & & & \\
I.M 3 & $460.00 \pm 144.43$ & $11.50 \pm 11.63$ & 0.922 & 0.368 \\
\hline
\end{tabular}

Table (13): Shows statistically significant difference between Zero and six months according to SC and IM in group 3.

\begin{tabular}{lcccc}
\hline & Group III & $\begin{array}{c}\text { Diff. from } \\
0-6 \%\end{array}$ & $\begin{array}{c}\text { Paired } \\
\text { sample } t \text {-test }\end{array}$ & $p$-value \\
\hline S.C 0 & $600.00 \pm 184.09$ & & & \\
S.C 6 & $367.00 \pm 175.91$ & $38.92 \pm 21.42$ & 2.902 & $0.010^{*}$ \\
I.M 0 & $520.00 \pm 147.57$ & & & \\
I.M 6 & $455.00 \pm 139.84$ & $12.27 \pm 11.61$ & 1.016 & 0.323 \\
\hline
\end{tabular}

\section{DISCUSSION}

To the best of our knowledge, this research is the first to study the anthropometric measurements of Middle Eastern buttock including thirty candidates with age ranging from eighteen to forty years who were satisfied by their buttock aesthetic appearance. The analysis revealed that the anthropometric measurements of the middle eastern buttock are slightly different than the aesthetic ideal buttock measurements, as round shape is the dominant shape in $70 \%$ of middle eastern buttock while pear shape is the dominant one in $85 \%$ of aesthetic ideal buttock [10]. The aesthetic ideal buttock depends directly on the relationship analysis of gluteus muscle with the other anatomical structures [9].

Results were so close in the three groups, especially six months post-operatively but it can't be deny that group one was the closest one and group three was the least one to the control group and this proof that the relationship analysis of the anatomical structures of the framework was the main cause of the aesthetic ideal buttock, for that reason group one needed the least amount of fat grafting (less than $400 \mathrm{cc}$ ) in comparison to group three (more than $800 \mathrm{cc}$ ).

Fat survival rate of injected fat in both subcutaneous and intramuscular planes in the gluteal area in group one was about $68.5 \%$ in the subcutaneous plane and $87.5 \%$ in the intramuscular one, while in group two was $65.5 \%$ in the subcutaneous plane and $87.5 \%$ in the intramuscular one and in group three was $62 \%$ in the subcutaneous plane and $88 \%$ in the intramuscular one.
So this means that fat survival rate of fat injected in subcutaneous plane decreases with increasing volume of fat injected, while in the intramuscular plane the survival rate the same and doesn't affect significantly.

In 2006, Mendiata stated the survival rate was about $65 \%$ in the subcutaneous plane while about $90 \%$ in the intramuscular one, [10] Murillo in 2014 revealed that the fat survived in the subcutaneous plane also the same results about $64 \%$ and in the intra muscular was $80 \%$ [10].

This current study and other studies showed that percentage of fat survival in the intramuscular plane was higher than the subcutaneous one from $16 \%$ to $25 \%$ and this is due to the high vascularity of intramuscular plane.

In 2015, Cardenas identified that, although fat survival is greater when injected into muscle, its grafting into muscular tissue increases the risk of fat embolism, therefore intramuscular lipografting is a procedure that should be performed very carefully to avoid injury to the deep gluteal vessels, [12] also in the same year, Abboud stated that maximizing the contacts between the fat grafts and the recipient sites by creating multiple access points for tunnelization and grafting and by multiplanner delivery of fat encourage revascularization and improve survival of fat grafts through multidirectional and multilayered fashion to prepare a matrix at the recipient site which ensures the maximal space for fat grafting and limits the size of the injected fat lobules [12].

Death from gluteal augmentation through intramuscular fat grafting by a fatal pulmonary fat embolism (PFE) did not gain widespread attention until Cardenas-Camarena published in 2015 a retrospective study reporting 22 deaths in Mexico and Columbia over a 15 -year period attributed to PFE after gluteal fat grafting. Because of increasing awareness of significant patient morbidity and mortality, the Aesthetic Surgery Education and Research Foundation (ASERF) formed a task force to examine the risk of PFE associated with gluteal fat grafting. Their data suggest the annual mortality rate from PFE secondary to gluteal fat grafting to be $1: 3448$, although they estimate the actual mortality rate may be as high as 1:2351 or greater [13].

Autopsy reports and photographs of the Cardenas-Camarena and his colleagues [12] demonstrated both micro- and macroscopic fat deposits in patients gluteal veins, vena cava, pulmonary arteries, and ventricles consistent with fat emboli as a direct cause of death. The exact mechanism of introduc- 
tion of fat into systemic circulation is unknown; however, it is thought to be caused by either direct cannulation of the large gluteal vessels or the creation of a pressure gradient, due to lack of particle dispersion over several layers of tissues, and subsequent flow of fat into the low-pressure veins. In 2017, Mofid also mentioned that the cause of fat embolism during gluteal augmentation procedures is the inadvertent entry of fat into the deep gluteal veins [14]. The mechanistic details underlying this event are not definitively known, and this represents one of several areas ripe for further research. Some postulate that venous fat embolism results from inadvertent cannulation of a vein with subsequent intraluminal grafting of fat. Others theorize that it can result from the "passive" siphoning of perivascular fat into a torn or lacerated vein that is characterized by a greater sub atmospheric pressure relative to the surrounding extra vascular space.

In 2016, Conde' identified that the actual mortality rate from pulmonary fat embolisms, is significantly greater than 1:4000 and this puts the mortality risks from gluteal lipografting possibly 10 to 20 times greater than the average mortality rate from aesthetic surgery procedures [15].

In 2018, Ramos reported that grafting of fat into the subcutaneous plane and into the superficial to midmuscular plane experienced $63 \%$ and $82 \%$ risk reductions respectively of pooled fatal and non-fatal pulmonary fat embolisms (PFE). In contrast, those reporting grafting into the deep muscular plane experienced a $403 \%$ increase in the risk of pooled fatal and nonfatal PFE [16].

Subcutaneous-only gluteal fat grafting is now increasingly recommended over intramuscular grafting to improve safety. Despite the perception that subcutaneous grafting results in less volume retention [17].

In this current study, few complications were encountered in seven patients; six patients having asymmetry six months postoperatively, two of them were observed by patients and the other four patients noticed only by surgeons. Although the amount of injected fat was equal bilaterally, this asymmetry might be due to the unequal fat resorption rate of both sides. The seventh patient developed unilateral gluteal abscess, this could be explained by her prior grafting of permanent filler in her buttock two years before.

No deaths were encountered, and it could be explained by following proper ways of grafting as avoiding grafting in an angle more than 45 degree, grafting in superficial to mid muscular plane and avoiding grafting into the deeper plane.

Recently, in 2019, Florida Board of Medicine (ISAPS, 2019), issued an emergency gluteal fat grafting rule which mandates that when performing gluteal fat grafting procedures, fat must be injected only into the subcutaneous space and must never cross the gluteal fascia. Intramuscular or sub muscular fat grafting is prohibited [17].

We started our study in 2017 before Florida Board of medicine recommendations, so we published this study to share our results of gluteal fat grafting either; subcutaneous or Intramuscular planes. This study recommends fat grafting through multidirectional and multilayered fashion to maximize fat survival rate. Intramuscular gluteal fat grafting showed higher survival rate, Some precautions were taken in consideration to minimize the risk of fat embolism as regards keeping the patient well hydrated through the first twenty four hours, avoiding intramuscular fat grafting in the dangerous zone, avoiding use cannula over $4 \mathrm{~mm}$ with single hole, and direction of grafting should be parallel to the gluteus maximus and not to be angulated downwards.

In July 2018, an urgent warning to surgeons performing fat grafting to the buttocks was released by ISAPS, they recommended fat injection to be placed in the subcutaneous tissue rather than intramuscular plane. As we started our study before this warning, and there was no mortality in our cases of intramuscular fat injection, we also warn surgeons from trying intramuscular fat injection without anticipating problems and also without taking in consideration these precautions and recommendations especially in large volume grafting.

Also, we recommend authors to perform more studies in Middle Eastern buttocks for more control cases to confirm the anthropometric criteria of Middle Eastern buttocks.

\section{REFERENCES}

1- Jorge Enrique Bayter-Marin, M.D. et al.: Understanding Fatal Fat Embolism in Gluteal Lipoinjection: A Review of the Medical Records and Autopsy Reports of 16 Patients PRS, 142 (5): 1198-1208, 2018.

2- Mendieta C.G.: Gluteoplasty. Aesthetic Surgery Journal, 23 (6): 441-55, 2003.

3- Pereira L.H. and Radwansky H.: Fat grafting of the buttock and lower limbs. Aesthetic Plast. Surg., 20: 409, 1996.

4- Mendieta C.G.: Classification system for gluteal evaluation. Clin. Plast. Surg., 33 (3): 333-46, 2006. 
5- Mofid M.M., Gonzalez R., de la Peña J.A., Mendieta C.G., Senderoff D.M. and Jorjani S.: Buttock augmentation with silicone implants: A multicenter survey review of 2226 patients. Plast. Reconstr. Surg., 131 (4): 897-901, 2013.

6- Ho Quoc, et al.: Ann. Chirp Last Esthat., 58 (3): 194-200, 2013.

7- Ford R.D. and Simpson W.D.: Massive extravasation of traumatically ruptured buttock silicone prosthesis. Ann. Plast. Surg., 29: 86, 1992.

8- American Society of Plastic Surgeons. 2016 plastic surgery statistics. Available at: https://www.plasticsurgery.org/ documents/ News/Statistics/2016/plastic-surgery-statisticsfullreport-2016.pdf. Accessed January 13, 2018.

9- Mendieta C.G.: The Art of Gluteal Sculpting. New York: Thieme, 2011.

10- Mendieta C.G.: Intramuscular gluteal augmentation technique. Clin. Plast. Surg., 33 (3): 423-34, 2006.

11- Murillo W.L.: Buttock augmentation: Case studies of fat injection monitored by magnetic resonance imaging. Plast. Reconst. Surg., 114: 1606-1614, 2014.
12- Cardenas-Camarena L., Bayter J.E., Aguirre-Serrano H. and Cuenca-Pardo J.: Deaths caused by gluteal lipoinjection: What are we doing wrong? Plast. Reconstr. Surg., 136 (1): 58-66, 2015.

13- Abboud M.H. and Dibo S.A.: Immediate large-volume grafting of autologous fat to the breast following implant removal. Aesthet. Surg. J.., 35 (7): 819-829, 2015.

14- Mofid M.M., Teitelbaum S., Suissa D., Ramirez-Montanana A., Astarita D.C., Mendieta C., et al.: Report on mortality from gluteal fat grafting: Recommendations from the ASERF Task Force. Aesthet. Surg. J., 37 (7): 796-806, 2017.

15- Condé-Green A., Kotamarti V., Nini K.T., et al.: Fat Grafting for Gluteal Augmentation: A Systematic Review of the Literature and Meta-Analysis. Plast. Reconstr. Surg., 138 (3): 437e-446e, 2016.

16- Ramos-Gallardo G., Orozco-Renteria D., Medina-Zamora P., et al.: Prevention of fat embolism in fat injection for gluteal augmentation: Anatomic study in fresh cadavers. J. Invest. Surg., 31: 292-297, 2018.

17- International Society of Aesthetic Plastic Surgery. Available at: https://www.isaps.org/blog Accessed June 6, 2019. 